\title{
ANALISIS KANDUNGAN FORMALIN DAN UJI ORGANOLEPTIK IKAN ASIN YANG BEREDAR DI PASAR BESAR MADIUN
}

\author{
Nia Surya Wijayanti ${ }^{1)}$, Marheny Lukitasari ${ }^{2)}$ \\ ${ }^{1,2)}$ Pendidikan Biologi FPMIPA IKIP PGRI Madiun. \\ email : nia_surya@yahoo.co.id ${ }^{1)}$, marh33ny@gmail.com ${ }^{2)}$
}

Diterima 20 Desember 2015, Disetujui 11 Maret 2016

\begin{abstract}
This study aims to determine the content of formaldehyde used as a preservative in dried fish that circulate in the Great Market Madiun and organoleptic salted fish containing formalin. The samples in this study used purposive sampling is a sampling technique with specific considerations. Two salted fish samples taken in the North, two samples were taken in the south, two samples were taken in the West, two samples were taken in the east, and two samples were taken in the central Great Market Madiun. Questionnaire data collection using questionnaires and documentation. Results showed that the formaldehyde content in dried fish balur, peda, and teri can be determined with Fehling method. If salted fish samples (+) containing formalin there will be changes color from blue to green color and there are deposits of red brick, while the sample () containing formalin will remain blue when heated and there is a brick red precipitate. Of 30 samples of dried fish salted fish only 1 (-) contain formaldehyde, which is peda salted fish west. Organoleptic clean white color most preferred by the panelists as much as $92 \%$ panelists found in samples dried fish balur middle east. Is not the typical organoleptic flavor of salted fish most preferred by the panelists as much as $78 \%$ of the panelists found in fish samples salted teri east. Organoleptic chewy texture intact most preferred by the panelists as much as $88 \%$ and there is a panelist on the samples salted fish teri middle.
\end{abstract}

Keywords: Formalin, Organoleptic Test, Salted Fish

\section{PENDAHULUAN}

Indonesia terkenal sebagai negara agraris dan bahari, wilayah negara Republik Indonesia yang sebagian besar merupakan lautan menyebabkan banyak tumbuhnya industri perikanan. Hasil tangkapan ikan oleh nelayan biasanya tidak dapat diangkut ke pasar karena segala keterbatasan. Upaya untuk mengatasi hal tersebut, sebagian nelayan dan pedagang ikan mengawetkannya agar tidak cepat membusuk. Pengawetan ikan secara tradisional bertujuan untuk mengurangi kadar air dalam tubuh ikan, salah satu caranya adalah dengan pembuatan ikan asin.

Pengolahan ikan menjadi ikan asin adalah cara pengawetan tradisional yang masih banyak dilakukan di berbagai negara, termasuk Indonesia. Meskipun ikan asin sangat digemari oleh masyarakat, ternyata pengetahuan masyarakat mengenai ikan asin yang aman dan baik untuk dikonsumsi masih kurang. Berbagai bukti banyaknya ikan asin yang mengandung formalin untuk mengawetkan, padahal dampaknya sangat merugikan kesehatan (Sri, 2010).

Bahan pengawet makanan menurut Leni (2010: 33) adalah bahan tambahan pangan yang dapat mencegah dan menghambat fermentasi, pengasaman atau penguraian, dan perusakan lainnya terhadap pangan yang disebabkan oleh mikroorganisme. Zat pengawet makanan dapat dibedakan menjadi tiga jenis yaitu, pertama GRAS (Generally Recognized as 
Safe), yang biasanya bersifat alami sehingga tidak menimbulkan efek racun pada tubuh. Kedua, pengawet yang ditentukan pemakaiannya oleh ADI (Acceptable Daily Intake), yang disesuaikan dengan batas penggunaan hariannya untuk kesehatan konsumen. Ketiga, zat pengawet yang tidak layak dikonsumsi sama sekali, seperti boraks dan formalin.

Formalin $\left(\mathrm{CH}_{2} \mathrm{O}\right)$ merupakan suatu larutan yang tidak berwarna, berbau tajam yang mengandung kurang lebih $37 \%$ formaldehid dalam air yang biasanya ditambahkan metanol $10-15 \%$ berfungsi sebagai stabilator agar tidak terjadi polimerasi (Nursanti, 2008: 29). Formalin sebenarnya bukan merupakan bahan tambahan makanan, bahkan merupakan zat yang tidak boleh ditambahkan pada makanan. Orang yang mengkonsumsi bahan pangan (makanan) seperti tahu, mie, bakso, ayam, ikan dan bahkan permen, yang berformalin dalam beberapa kali saja belum merasakan akibatnya. Tapi efek dari bahan pangan (makanan) berformalin baru bisa terasa beberapa tahun kemudian.

Penggunaan formalin pada ikan asin yang bertujuan untuk pengawetan agar tidak ditumbuhi jamur sekaligus untuk meningkatkan bobot ikan asin. Pembuatan ikan asin dengan menambahkan garam tanpa penambahan formalin menghasilkan penyusutan sekitar $40 \%$ sedangkan ikan asin dengan penambahan formalin bobotnya meningkat menjadi $75 \%$, serta kenampakan ikan asin lebih bersih dan utuh (Tri dan Erni, 2006). Penggunaan bahan pengawet cenderung lebih menguntungkan maka diduga banyak ikan asin yang mengandung formalin termasuk di Pasar Besar Madiun.

Penjual ikan asin di Pasar Besar Madiun menjual bermacam-macam ikan asin, misalnya balur, peda, dan teri. Ikan asin yang dijual oleh pedagang kebanyakan memiliki ciri-ciri dengan warna putih bersih mengkilap, teksturnya lebih keras dan jarang dihinggapi oleh lalat, yang menunjukkan ciri-ciri ikan dengan kandungan pengawet formalin. Hasil penelitian Tri dan Erni (2006) menunjukkan bahwa ikan asin yang mengandung formalin dagingnya akan kenyal, utuh, warna lebih putih dan bersih di banding ikan asin tanpa formalin, sedangkan menurut penelitian Rinto, Elmeizi, Susila (2009) menunjukkan bahwa ikan asin yang mengandung formalin berwarna putih cerah, dagingnya tidak mudah hancur dan tidak beraroma khas ikan.

Menurut penelitian Rinto et al., (2009) ikan asin yang mengandung formalin dapat diuji dengan menggunakan uji organoleptik, dengan ciri ikan asin berwarna lebih cerah, dagingnya tidak mudah hancur dan tidak beraroma khas ikan. Uji organoleptik merupakan penilaian mutu produk berdasarkan panca indera manusia melalui syaraf sensorik seperti sifat kenampakan (bentuk, ukuran, warna), tekstur yaitu yang dinilai dari indra peraba (halus, kasar, lembut). Uji organoleptik banyak digunakan untuk menilai mutu suatu produk terutama produk hasil pertanian dan makanan (Wawan, 2005).

Menurut Windo (2008) ikan sebagai bahan makanan yang mengandung protein tinggi dan mengandung asam amino esensial yang diperlukan oleh tubuh, disamping itu nilai biologisnya mencapai 90 persen, dengan jaringan pengikat sedikit sehingga mudah dicerna. Proses pembusukan ikan tidak dapat dihindari tetapi bisa dihambat. Salah satu caranya adalah menekan perkembangan mikrobamikroba pembusuknya. Mikroba akan berkembangbiak lambat bila kondisi lingkungannya tidak optimal untuk hidupnya (Abbas, 1995). Produsen melakukan penghambatan pembusukan dengan cara penggaraman dan 
penggeringan yang dilakukan dengan memberi garam yang disebut dengan ikan asin.

Cara memilih ikan asin yang baik adalah dengan melihat warna dagingnya yang mendekati warna asli ikan segar, tidak berbau asam atau tengik, tak ada bercak-bercak noda, tidak lembek berair atau kaku (Teguh dan Elvina 1998). Menurut penelitian Desniar, et al., (2009) konsentrasi garam yang digunakan dalam fermentasi ikan peda sangat menentukan mutu ikan peda, disamping kesegaran bahan bakunya pemberian garam mempengaruhi jenis mikroba yang berperan dalam fermentasi garam merupakan bahan bakteriostatik untuk beberapa bakteri meliputi bakteri patogen dan pembusuk. Ikan teri (Stolephorus sp.) merupakan ikan penghuni perairan pesisir dan eustaria serta beberapa jenis dapat hidup pada perairan dengan salinitas 1015\%. Menurut Afrianto dan Liviawaty (dalam Windo, 2008) ikan teri kaya akan fosfor yang berfungsi untuk pembentukan tulang dan gigi. Jumlah kalori yang dapat dihasilkan dari 100 gram daging ikan teri mencapai 74 kalori, dengan rincian vitamin A, vitamin B, dan sumber mineral. Rini (2006) dalam penelitiannya mengemukakan pengujian organoleptik merupakan cara pengujian dengan indera manusia sebagai alat utama untuk pengukuran daya penerimaan terhadap makanan. Sasaran alat indera ditujukan terhadap kenampakan, bau dan tekstur.

\section{METODE PENELITIAN}

Penentuan sampel dalam penelitian ini menggunakan simple random sampling yaitu teknik pengambilan sampel secara acak. Pengambilan sampel ikan asin dilakukan di Pasar Besar Madiun, yaitu 2 pedagang di sebelah utara, 2 pedagang di sebelah selatan, 2 pedagang di sebelah barat, 2 pedagang di sebelah timur, dan 2 pedagang di sebelah tengah.
Alat dan bahan yang digunakan adalah: timbangan atau neraca analitik 1; beaker glass $400 \mathrm{ml} \mathrm{1}$; beaker glass $100 \mathrm{ml}$ 30; tabung reaksi 30; pipet ukur 3; gelas ukur $50 \mathrm{ml} \mathrm{1;} \mathrm{penanggas} \mathrm{strring} \mathrm{hot} \mathrm{plate} \mathrm{1;}$ pisau; ikan asin balur 2 gram; ikan asin peda 2 gram; ikan asin teri 2 gram; aquades; air panas; Sampel ikan asin balur; peda dan teri, fehling A dan fehling B.

\section{Prosedur Penelitian Uji Fehling}

Menyiapkan alat dan bahan yang diperlukan, memberi label pada masingmasing sampel ikan asin. Menimbang sampel ikan asin sebanyak 2 gram dan meletakkannya pada beaker glass berukuran $100 \mathrm{ml}$. Memasukkan air panas ke dalam sampel ikan asin yang berada di beaker glass tadi sebanyak $15 \mathrm{ml}$, lalu diaduk. Memasukkan cairan sampel masing-masing kedalam tabung reaksi sebanyak $2 \mathrm{ml}$. Menetesi fehling A dan fehling B masing-masing sebanyak $1 \mathrm{ml}$, lalu kocong sampai warna berubah menjadi biru. Memasukkan aquades sebanyak 300 $\mathrm{ml}$ kedalam beaker glass dan memanaskannya di atas penanggas air. Memasukkan tabung reaksi yang sudah ditetesi fehling kedalam aquades yang telah dipanaskan. Mengamati perubahan warna yang terjadi, apabila warna biru berubah menjadi warna hijau dan terdapat endapan berwarna merah maka sampel ikan asin tersebut positif (+) mengandung formalin.

\section{Prosedur Penelitian Uji Organoleptik}

Menyediakan 30 sampel ikan asin yang akan diuji. Meminta panelis untuk melakukan uji organoleptik dengan cara meraba tekstur, mencium aroma dan melihat warna ikan asin yang telah disedikan. Selanjutnya, panelis dapat mengisi angket yang telah disediakan. Data yang telah diperoleh nantinya akan dianalisis secara diskriptif. 


\section{HASIL DAN PEMBAHASAN}

Berdasarkan uji kandungan formalin pada ikan asin balur, peda, dan teri ini dilakukan dengan metode uji fehling (gugus aldehid) agar dapat dijadikan sebagai penyusun panduan praktikum pada mata kuliah Biokimia. Uji kualitatif formalin pada ikan asin menggunakan metode fehling yaitu menggunakan fehling A dan fehling B. Berdasarkan hasil pengamatan dari hasil uji laboratorium kandungan formalin pada 30 sampel ikan asin yang di jual di Pasar Besar Madiun didapatkan hasil sebanyak 29 sampel ikan asin (+) mengandung formalin, dan $1(-)$ mengandung formalin. Indikasinya apabila sampel (+) mengandung formalin terjadi perubahan warna menjadi hijau dan terdapat endapan berwarna merah bata. Sejalan dengan hasil penelitian Ika (2007) jika terdapat endapan merah bata maka sampel positif (+) mengandung formalin. Ikan asin peda barat 1 merupakan ikan asin yang tidak mengandung formalin dengan indikasi (-), apabila dipanaskan tidak akan terjadi perubahan warna atau tetap berwarna biru tua. Ikan asin teri merupakan ikan asin yang mengandung formalin paling sedikit, karena warnanya yang dominan kuning dan rata-rata hanya terindikasi $(+)$, beda dengan ikan asin balur dan ikan asin peda.

Uji organoleptik merupakan pengujian dengan indera manusia sebagai alat utama untuk mengukur mutu makanan. Winarno (2004) berpendapat bahwa warna suatu bahan pangan mempunyai peranan penting dalam penentuan mutu serta mempunyai daya tarik untuk konsumen, sehingga konsumen dapat memberi kesan suka atau tidak suka dengan cepat. Aroma suatu produk dapat dinilai dengan cara pembauan. Penelitian Rinto et al., (2009) mengemukakan aroma merupakan satu parameter yang menentukan ikan asin. Hasil uji organoleptik warna pada ikan asin menunjukkan warna ikan asin putih bersih paling banyak dipilih oleh panelis dan paling banyak panelis menilai pada sampel balur tengah yaitu sebanyak $92 \%$ panelis. Warna coklat merupakan warna yang paling sedikit dipilih oleh panelis yaitu sebanyak $2 \%$ pada ikan balur sebelah selatan dan tengah.

Hasil uji organoleptik aroma pada ikan asin menunjukkan aroma tidak khas ikan asin paling banyak dipilih oleh panelis dan paling banyak panelis menilai pada sampel teri timur yaitu sebanyak $78 \%$ panelis. Aroma khas ikan asin merupakan aroma paling sedikit dipilih oleh panelis yaitu sebanyak $22 \%$ panelis pada sampel teri timur. Hasil uji organoleptik tekstur pada ikan asin menunjukkan tekstur kenyal dan utuh paling banyak dipilih oleh panelis, yaitu sebanyak $88 \%$ terdapat pada sampel ikan asin teri tengah. Tekstur ikan asin mudah hancur paling sedikit dipilih oleh panelis, yaitu sebanyak $12 \%$ panelis pada sampel teri tengah.

\section{KESIMPULAN DAN SARAN}

\section{Simpulan}

Terdapat kandungan formalin pada ikan asin yang di jual di Pasar Besar Madiun. Kandungan formalin pada ikan asin balur, peda, dan teri dapat diketahui dengan metode fehling. Uji organoleptik ikan asin balur, peda, dan teri berpengaruh terhadap penilaian panelis yang berupa warna, aroma, tekstur. Ikan asin yang mengandung formalin berwarna putih bersih, aromanya tidak khas ikan asin, dan teksturnya lebih kenyal utuh. Warna putih bersih paling banyak dinilai oleh panelis dan berada pada sampel ikan asin balur tengah. Aroma tidak khas ikan asin paling banyak dinilai oleh panelis dan berada pada sampel ikan asin teri timur. Tekstur ikan asin kenyal utuh paling banyak dipilih oleh panelis dan berada pada sampel ikan asin teri tengah. 


\section{Saran}

Uji kandungan ikan berformalin sebaiknya juga dilakukan pada ikan segar, dengan menggunakan metode yang berbeda, sehingga tingkat validasinya semakin tinggi

\section{DAFTAR PUSTAKA}

Abbas Siregar. (1995). Ikan Asin. Yogyakarta: Kanisius

Desniar, Peornomo D, dan Wijatur. (2009). Pengaruh Konsentrasi Garam Pada Peda Ikan Kembung (Rastrelliger sp.) dengan Fermentasi Spontan. Jurnal Pengolahan Hasil Perikanan Indonesia (Online), Vol XII No. 1 Tahun 2009, (http://repository.ipb.ac.id/bitstream/ handle/123456789/42615/Desniar_P engaruhKonsentasiGaramPadaPeda. pdf, Diunduh 24 Maret 2013).

Winarno. (2004). Kimia Pangan dan Gizi. Jakarta: PT Gramedia Pustaka Utama

Henny Putri. (2012). Studi Identifikasi Kandungan Formalin Pada Ikan Pindang Di Pasar Tradisional Dan Modern Kota Semarang, Jurnal Kesehatan Masyarakat (Online), Volume 1, Nomor. 2, Halaman 983994.

(http://ejournals1.undip.ac.id/index. php/jkm1385/1406) Diakses 21 Februari 2013).

Ika Wulandari. (2007). Pemeriksaan Kandungan Folhaldehid Berdasarkan Perbedaan Suhu Air Yang Dimasukkan Kedalam Peralatan Makan Melamin Yang Beredar Di Kota Medan Tahun 2007 (Online), (http://repository.usu.ac.id/bitstream /123456789/14781/1/08E00925.pdf, Diunduh 20 Juni 2013).
Leni Herliani. (2010). Pengawet Makanan Alami dan Sintetis. Bandung: Alfabeta

Rini Susianawati. (2006). Kajian Penerapan GMP dan SSOP Pada Produk Ikan Asin Kering Dalam Upaya Peningkatan Keamanan Pangan Di Kabupaten Kendal, (Ounline), (http://eprints.undip.ac.id/15826/1/R ini_Susianawati.pdf, Diunduh 5 April 2013).

Rinto, Elmeizi, Susila. (2009). Kajian Keamanan Pangan (Formalin, Garam, Dan Mikrobia) Pada Ikan Sepat Asin Produksi Indralaya, Jurnal Pembangunan Manusia (Online) Vol.8 No.2 tahun 2009, (http://balitbangnovda.sumselprov.g o.id/data/download/2010041413092 7.pdf).Diakses 5 April 2013)

Sri Hastuti. (2010). Analisis Kualitatif Dan Kuantitatif Formaldehid Pada Ikan Asin Di Madura Argointek (Online) Vol.4 No.2 Agustus 2010, (http://pertanian.trunojoyo.ac.id/wpcontent/uploads/2011/01/JURNAL7 -Analisis-Kualitatif-dan-KuantitatifFormaldehid-pada-Ikan-Asin-diMadura.pdf) Diakses 3 April 2013)

Supli Effendi. (2009). Teknologi Pengolahan dan Pengawetan Pangan. Bandung: Alfabeta

Teguh Sudarisman, Elvina A.R. (1996). Petunjuk Memilih Produk Ikan Dan Daging. Jakarta: Penebar Swadaya.

Teti R., Skalalis D., Sei Astuty. (2003). Pegasinan Ikan Teri (Stolephorus spp.) dan Kelayakan Usahanya Di Desa Karanghantu Serang (Online) (http://pustaka.unpad.ac.id/wpconte nt/uploads/2009/07/pengasinan_ikan teri.pdf).Diakses 23 Maret 2013). 
Windo Sastra. (2008). Fermentasi Rusip (Online),

(http://repository.ipb.ac.id/bitstream/ handle/123456789/5420/C08wsa.pd

f?sequence $=4$ Diakses5 April 2013) 